\title{
METACORTANDRACIN AND 9-ALPHA-FLUORO HYDROCORTISONE ACETATE IN RHEUMATIC DISEASES
}

\author{
BY \\ L. VILlA, C. B. BALLABIO, AND G. SALA \\ From the Rheumatological Department of the Medical Clinic of the University of Milan
}

(RECEIVED FOR PUBLICATION MAY 6, 1955)

Among the pharmacological problems, raised by the study of the biological properties of cortisone is the existence of other substances exhibiting the same or similar properties.

Hydrocortisone is already in practical use, and although not much more active than cortisone, in the acetate form it presents greater local antiphlogistic activity. Aldosterone which has been introduced into medical use in the last 2 years, has a marked action on electrolyte metabolism, but its antiphlogistic action is nil. Recently three new steroids possessing anti-inflammatory properties superior to those of cortisone have been reported: 9- $x$-fluoro hydrocortisone (Boland and Headley, 1954; Ward and others, 1954), metacortandralone and metacortandracin (Bunim and others, 1955; Ballabio and others, 1955, a, b; Sala and others, 1955, a, b).

Bunim states that metacortandralone represents a great step forward in the treatment of rheumatic diseases with adrenal hormones because it is three or four times more active than cortisone, and does not affect the electrolyte and the nitrogen metabolism unfavourably, at least within the limits of therapeutically active doses.

This report deals with our clinical experience in the last 3 months in the treatment of rheumatic diseases with metacortandracin and 9- $\alpha$-fluoro hydrocortisone.

\section{Material}

This study was conducted with 36 patients, some of whom have been under our control for several years. This facilitated comparison with previous treatments, as the results could be exactly defined over a long period.

\section{Methods}

Both steroids were administered orally; the total daily dosage was divided into three or four doses, according to quantity.

Initial "suppressive" doses were gradually reduced to the minimum maintenance dose. The initial dose was approximately $30-50 \mathrm{mg}$. for metacortandracin and 8-16 mg. for 9-x-fluoro hydrocortisone. The main- tenance doses varied widely from case to case, ranging from 15 to $30 \mathrm{mg}$. $/ 24 \mathrm{hrs}$ for metacortandracin, and from 6 to $8 \mathrm{mg}$. for $9-x$-fluoro hydrocortisone. The duration of treatment was determined by the clinical course; in some cases treatment is still being continued and follows the schemes of long-term treatment already devised for cortisone. The laboratory tests used were as set out in Table I.

TABLE I

LABORATORY TESTS

\begin{tabular}{|c|c|c|}
\hline \multirow{2}{*}{ Investigation } & \multicolumn{2}{|l|}{ Method } \\
\hline & Authors & Date \\
\hline $\begin{array}{l}\text { Antistreptolysin titre } \\
\text { Serum mucoproteins } \\
\text { Plasma and urinary sodium } \\
\text { and potassium (by flame } \\
\text { photometry) } \\
\text { Plasma chloride } \\
\text { Urinary chloride } \\
\text { Serum carbon dioxide } \\
\text { Plasma and urinary endo- } \\
\text { genous creatinine } \\
\text { Total body fluids } \\
\text { Extracellular fluids } \\
\text { Blood glucose } \\
\text { Serum albumin and globulins } \\
\text { (by optical electrophoresis) } \\
\text { Total serum proteins } \\
\text { Total plasma cholesterol } \\
\text { Plasma uric acid } \\
\text { Urinary uric acid } \\
\text { Circulating eosinophils } \\
\text { Urinary } 17-\text { ketosteroids }\end{array}$ & $\begin{array}{l}\text { Rantz and Randall } \\
\text { Winzler } \\
\text { Mosher and others } \\
\text { Van Slyke and Hiller } \\
\text { Harvey } \\
\text { Van Slyke and Cullen } \\
\text { Bonsnes and Taussky } \\
\text { Soberman } \\
\text { Cachera and Lamotte } \\
\text { Hagedorn and Jensen } \\
\text { Tiselius } \\
\text { Phillips and Van Slyke } \\
\text { Bloor } \\
\text { Brown } \\
\text { Benedict and Franke } \\
\text { Dunger* } \\
\text { Callow and others }\end{array}$ & $\begin{array}{l}1949 \\
1947 \\
1910 \\
1915 \\
1945 \\
1950 \\
1923 \\
1923\end{array}$ \\
\hline
\end{tabular}

* Modified by Forsham and others, 1948.

\section{Results}

Anti-Rheumatic Activity.- - In all cases, a marked anti-rheumatic action followed the administration of metacortandracin and 9- $x$-fluoro hydrocortisone. All the patients showed a marked subjective improvement within a few days, with reduction of pain and stiffness and relief of aching on motion.

The objective improvement included disappearance or reduction of muscular and articular stiffness and swelling, and lessening of articular tenderness. The consequent improvement of articular function was clearly evident, so that in many cases there was a return of activity even greater than that obtained with previous cortisone treatment. The response 
PATIENTS RECEIVING CORTISONE, HYDROCORTISONE, 9- $\alpha$-FLUORO HYDRể $\alpha$

\begin{tabular}{|c|c|c|c|c|c|c|}
\hline Case No. & Sex & Age & Diagnosis & Stage & $\begin{array}{c}\text { Duration of } \\
\text { Arthritis } \\
\text { (yrs) }\end{array}$ & $\frac{\text { ल. }}{\text { D鹿 }}$ \\
\hline 1 & $\bar{F}$ & 70 & & IV & 20 & $\left\{\begin{array}{l}\text { Cortisб̄ne } \\
\text { Hydrofarti }\end{array}\right.$ \\
\hline 2 & $\mathbf{M}$ & 71 & & III-IV & 8 & $\left\{\begin{array}{l}\text { Cortisohe } \\
\text { Hydrocorti: }\end{array}\right.$ \\
\hline 3 & $\mathbf{F}$ & 30 & & II-III & 3 & $\left\{\begin{array}{l}\text { Cortisofiti } \\
\text { Hydro }\end{array}\right.$ \\
\hline 4 & F & 59 & & III-IV & 5 & \\
\hline 5 & $\mathbf{M}$ & 48 & & II & 1 & Cortisone \\
\hline $\begin{array}{r}6 \\
7 \\
8 \\
9 \\
10 \\
11 \\
12 \\
13\end{array}$ & $\begin{array}{l}\mathbf{M} \\
\mathbf{M} \\
\mathbf{F} \\
\mathbf{F} \\
\mathbf{F} \\
\mathbf{F} \\
\mathbf{F} \\
\mathbf{M}\end{array}$ & $\begin{array}{l}34 \\
54 \\
65 \\
58 \\
49 \\
51 \\
51 \\
58\end{array}$ & Rheumatoid arthritis & $\begin{array}{c}\text { II } \\
\text { II-III } \\
\text { II } \\
\text { III-IV } \\
\text { II } \\
\text { III-IV } \\
\text { II } \\
\text { II-III }\end{array}$ & $\begin{array}{r}3 \\
2 \\
3 \\
10 \\
4 \\
6 \\
5 \\
6\end{array}$ & $\begin{array}{l}\text { Cortisone } \\
\text { Cortisone } \\
\text { Cortisege } \\
\text { Cortisøge } \\
\text { Cortisøge } \\
\text { Cortisogne } \\
\text { Cortisofe } \\
\text { Cortisonte } \\
\text { Hydrogortis } \\
\end{array}$ \\
\hline $\begin{array}{l}14 \\
15\end{array}$ & $\begin{array}{l}\mathbf{M} \\
\mathbf{M}\end{array}$ & $\begin{array}{l}63 \\
40\end{array}$ & Psoriatic arthritis & $\begin{array}{l}\text { II-III } \\
\text { III-IV }\end{array}$ & $\begin{array}{l}4 \\
4\end{array}$ & 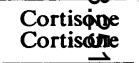 \\
\hline $\begin{array}{l}16 \\
17 \\
\end{array}$ & $\begin{array}{l}\mathbf{M} \\
\mathbf{F}\end{array}$ & $\begin{array}{r}27 \\
9\end{array}$ & Still-Chauffard disease & II-III & $\begin{array}{l}2 \\
3 \\
\end{array}$ & $\begin{array}{l}\text { Cortisque } \\
\text { Cortisome }\end{array}$ \\
\hline $\begin{array}{l}18 \\
19\end{array}$ & $\begin{array}{l}\mathbf{F} \\
\mathbf{F}\end{array}$ & $\begin{array}{l}21 \\
69 \\
\end{array}$ & Rheumatic fever & $\begin{array}{l}\text { Acute phase } \\
\text { Acute phase }\end{array}$ & - & $\underset{\infty}{\infty}$ \\
\hline $\begin{array}{l}20 \\
21 \\
22 \\
23 \\
24\end{array}$ & $\begin{array}{l}\mathbf{M} \\
\mathbf{F} \\
\mathbf{F} \\
\mathbf{M} \\
\mathbf{F}\end{array}$ & $\begin{array}{r}7 \\
36 \\
44 \\
19 \\
17\end{array}$ & Rheumatic carditis & $\begin{array}{l}\text { Active } \\
\text { Active } \\
\text { Active } \\
\text { Active } \\
\text { Active }\end{array}$ & $\begin{array}{l}1 \\
4 \\
1 \\
1 \\
3\end{array}$ & $\frac{-10}{-3}$ \\
\hline 25 & $\mathbf{M}$ & 13 & Rheumatic pancarditis & Acute phase & $\frac{1}{2}$ & \\
\hline 26 & $\mathbf{M}$ & 31 & Viscerocarditis & Acute phase & $\frac{1}{2}$ & Cortist \\
\hline 27 & $F$ & 23 & Lupus erythematosus & Subacute phase & 1 & $\left\{\begin{array}{l}\text { Corisen } \\
\text { Hydroørtis }\end{array}\right.$ \\
\hline $\begin{array}{l}28 \\
29 \\
30 \\
31\end{array}$ & $\begin{array}{l}\mathbf{F} \\
\mathbf{M} \\
\mathbf{M} \\
\mathbf{M}\end{array}$ & $\begin{array}{l}64 \\
50 \\
60 \\
35\end{array}$ & Chronic gout & $\begin{array}{c}\text { III-IV } \\
\text { II } \\
\text { II-III } \\
\text { II }\end{array}$ & $\begin{array}{r}10 \\
1 \\
5 \\
5\end{array}$ & 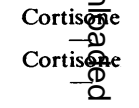 \\
\hline 32 & $\mathrm{~F}$ & 51 & Spondylo-arthritis & I & 4 & 을 \\
\hline $\begin{array}{l}33 \\
34\end{array}$ & $\begin{array}{l}F \\
F\end{array}$ & $\begin{array}{l}52 \\
66\end{array}$ & Osteo-arthritis & II & $\begin{array}{l}3 \\
5\end{array}$ & 常 \\
\hline $\begin{array}{l}35 \\
36\end{array}$ & $\begin{array}{l}\mathrm{M} \\
\mathrm{F}\end{array}$ & $\begin{array}{l}57 \\
57\end{array}$ & Scleroderma & $\begin{array}{l}\text { Severe } \\
\text { Moderate }\end{array}$ & $\begin{array}{r}1 \\
10\end{array}$ & $\begin{array}{l}\text { Cortisòie } \\
\text { Cortisêne }\end{array}$ \\
\hline
\end{tabular}

was rapid during the very first days of treatment and then became gradual; pain soon disappeared, but days or weeks were required to achieve the maximum effect on stiffness and swelling.

In most cases the local improvement was accompanied by disappearance of fever, haemopoietic stimulation, return of strength and appetite, increase of weight, and proportional euphoric state. This was similar to what has already been observed with Compounds $\mathrm{E}$ and $\mathrm{F}$, so that metacortandracin and 9 - $\alpha$-fluoro hydrocortisone may be said to possess all the anti-inflammatory and anti-rheumatic properties of cortisone and hydrocortisone.

The case-list contained in Table II shows that the indications for metacortandracin are the same as for cortisone.
A sharp decrease was observed in the sedimen $-\frac{3}{3}$ tation rate (Katz index), in some cases greater than' that obtained with cortisone. A decrease waş observed in serum mucoproteins similar to that obtained with cortisone. The antistreptolysin titre? decreased and in some cases reached values below those obtained with cortisone.

The electrophoretic pattern in some cases waso clearly modified but did not become completelyn normal: the most important changes were repre-N sented by albumin increase and a decrease of totaf globulins, especially of the fraction.

Treatment with cortisone, hydrocortisone, of른 both, had previously been given to 23 of the $36 \%$ patients studied.

In Table II the results obtained with previous 


\begin{tabular}{|c|c|c|c|c|}
\hline \multicolumn{2}{|c|}{; or Hydrocortisone Therapy } & \multicolumn{3}{|c|}{ Metacortandracin and $9-\alpha$-fluoro hydrocortisone Therapy } \\
\hline tenance Dose & Results & Drug & Maintenance Dose & Results \\
\hline $\begin{array}{l}75-100 \\
60-80 \\
50-75 \\
50-62 \\
100 \\
80 \\
50-75 \\
50 \\
100 \\
80 \\
60-70 \\
100 \\
50-75 \\
75-100 \\
50-75 \\
1100 \\
75 \\
70-80 \\
50-60\end{array}$ & $\begin{array}{l}\text { Moderate } \\
\text { Moderate } \\
\text { Moderate } \\
\text { Moderate } \\
\text { Moderate } \\
\text { Moderate } \\
\text { Moderate } \\
\text { Moderate } \\
\text { Moderate } \\
\text { Moderate } \\
\text { Moderate } \\
\text { Moderate } \\
\text { Moderate } \\
\text { Moderate } \\
\text { Marked } \\
\text { Marked } \\
\text { Moderate } \\
\text { Marked } \\
\text { Marked } \\
\end{array}$ & $\begin{array}{l}\text { Metacortandracin } \\
\text { Metacortandracin } \\
\text { Metacortandracin } \\
\text { Metacortandracin } \\
\text { Metacortandracin } \\
9-\alpha \text {-fluoro hydrocortisone } \\
9-\alpha \text {-fluoro hydrocortisone } \\
\text { Metacortandracin } \\
\text { Metacortandracin } \\
\text { Metacortandracin } \\
\text { Metacortandracin } \\
\text { Metacortandracin } \\
\text { Metacortandracin } \\
\text { Metacortandracin }\end{array}$ & $\begin{array}{c}20-25 \\
20 \\
25-30 \\
15-20 \\
35-40 \\
8-10 \\
8 \\
25 \\
15-20 \\
20 \\
20 \\
25 \\
25-20 \\
25-20\end{array}$ & $\begin{array}{l}\text { Moderate } \\
\text { Marked } \\
\text { Marked } \\
\text { Moderate } \\
\text { Marked } \\
\text { Marked } \\
\text { Marked } \\
\text { Marked } \\
\text { Marked } \\
\text { Marked } \\
\text { Marked } \\
\text { Marked } \\
\text { Marked } \\
\text { Marked }\end{array}$ \\
\hline $\begin{array}{c}75 \\
75-100\end{array}$ & $\begin{array}{l}\text { Marked } \\
\text { Moderate }\end{array}$ & $\begin{array}{l}\text { Metacortandracin } \\
\text { Metacortandracin }\end{array}$ & $\begin{array}{l}20 \\
\mathbf{3 0}\end{array}$ & $\begin{array}{l}\text { Very marked } \\
\text { Moderate }\end{array}$ \\
\hline $\begin{array}{l}75 \\
50\end{array}$ & $\begin{array}{l}\text { Moderate } \\
\text { Marked }\end{array}$ & $\begin{array}{l}\text { Metacortandracin } \\
\text { Metacortandracin }\end{array}$ & $\begin{array}{l}15 \\
15\end{array}$ & $\begin{array}{l}\text { Very marked } \\
\text { Marked }\end{array}$ \\
\hline - & 二 & $\begin{array}{l}\text { Metacortandracin } \\
\text { Metacortandracin }\end{array}$ & $\begin{array}{l}25 \\
25\end{array}$ & $\begin{array}{l}\text { Very marked } \\
\text { Very marked }\end{array}$ \\
\hline $\begin{array}{l}\overline{-} \\
\bar{z}\end{array}$ & $\overline{-}$ & $\begin{array}{l}\text { Metacortandracin } \\
\text { Metacortandracin } \\
\text { Metacortandracin } \\
\text { Metacortandracin } \\
\text { Metacortandracin }\end{array}$ & $\begin{array}{l}20 \\
25 \\
20 \\
20 \\
20\end{array}$ & $\begin{array}{l}\text { Marked } \\
\text { Marked } \\
\text { Marked } \\
\text { Marked } \\
\text { Marked } \\
\end{array}$ \\
\hline- & - & Metacortandracin & 25 & Marked \\
\hline 100 & Marked & Metacortandracin & 30 & Very marked \\
\hline $\begin{array}{l}50 \\
40 \\
\end{array}$ & $\begin{array}{l}\text { Marked } \\
\text { Very marked }\end{array}$ & $\left\{\begin{array}{l}\text { Metacortandracin } \\
9-\alpha \text {-fluoro hydrocortisone }\end{array}\right.$ & $\begin{array}{r}15 \\
8\end{array}$ & $\begin{array}{l}\text { Very marked } \\
\text { Very marked }\end{array}$ \\
\hline$\frac{75-100}{75}$ & $\begin{array}{c}\text { Moderate } \\
\text { Marked }\end{array}$ & $\begin{array}{l}\text { Metacortandracin } \\
\text { Metacortandracin } \\
\text { Metacortandracin } \\
\text { 9- } \boldsymbol{x} \text {-fluoro hydrocortisone } \\
\text { Metacortandracin }\end{array}$ & $\begin{array}{l}25 \\
20 \\
20 \\
4 \cdot 8 \\
15\end{array}$ & $\begin{array}{l}\text { Moderate } \\
\text { Very marked } \\
\text { Marked } \\
\text { Very marked } \\
\text { Very marked }\end{array}$ \\
\hline - & - & Metacortandracin & 25 & Moderate \\
\hline- & - & $\begin{array}{l}\text { Metacortandracin } \\
\text { Metacortandracin }\end{array}$ & 20 & $\begin{array}{l}\text { Marked } \\
\text { Marked }\end{array}$ \\
\hline .100 & $\begin{array}{l}\text { Moderate } \\
\text { Moderate }\end{array}$ & $\begin{array}{l}\text { Metacortandracin } \\
\text { Metacortandracin }\end{array}$ & 20 & $\begin{array}{l}\text { Moderate } \\
\text { Marked }\end{array}$ \\
\hline
\end{tabular}

cortisone and hydrocortisone treatments are compared with those obtained with metacortandracin therapy: the new steroid, in maintenance doses three to four times less than those required with cortisone, produces a greater effect.

Side-Effects. - Table III summarizes the secondary effects which were observed, those seen with cortisone treatment being used as a reference.

All the side-effects were transient and ceased when treatment was withdrawn.

Of all the data given in Table III the most important are those presumably related to increased corticoid activity. 


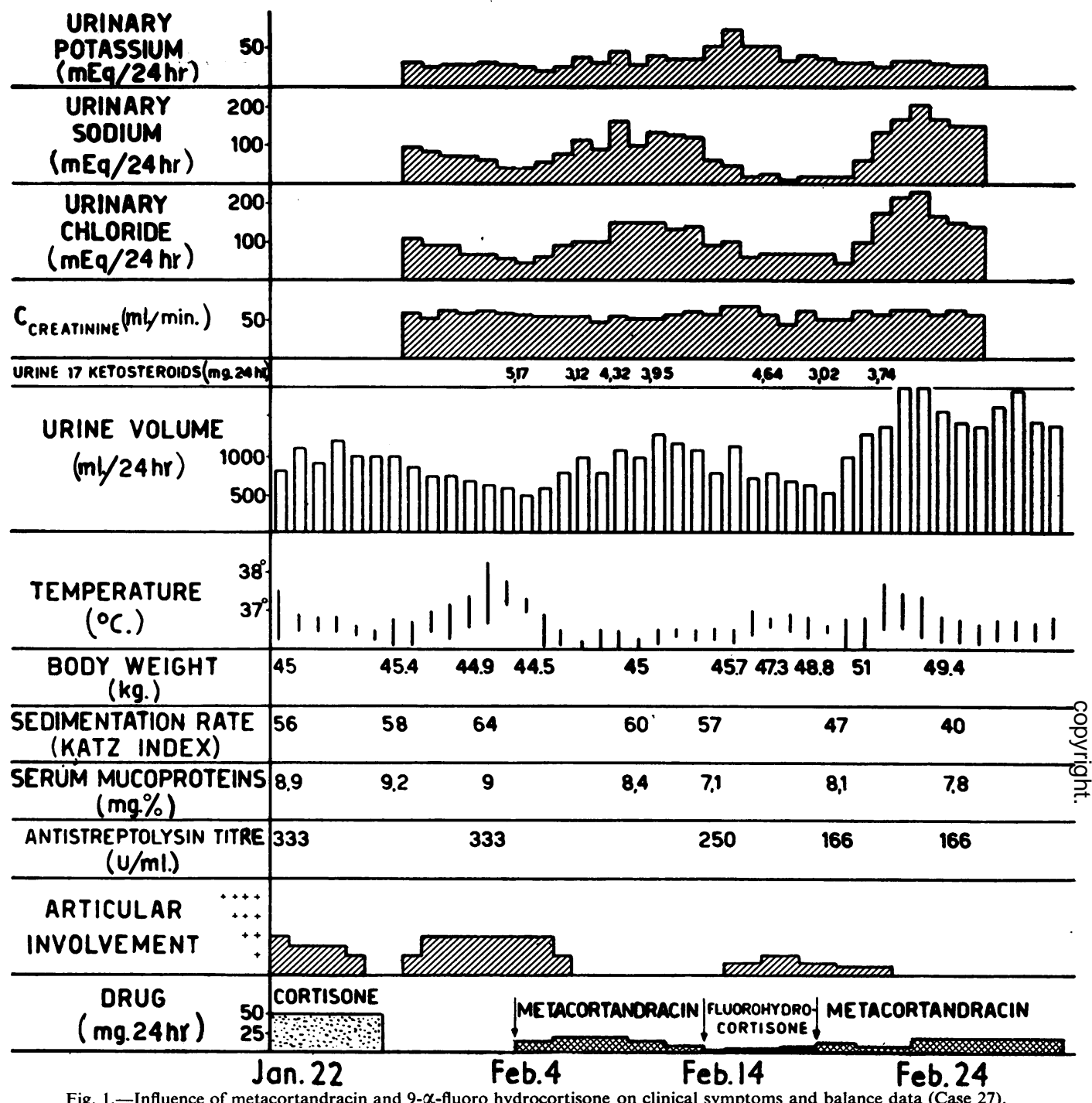

Fig. 1.-Influence of metacortandracin and $9-\alpha$-fluoro hydrocortisone on clinical symptoms and balance data (Case 27).

cortisone, when there were often rapid gains in weight (Figs 1 and 2, Cases 27 and 5).

Blood Pressure.-This is not modified by metacortandracin, but is constantly increased by $9-\alpha$-fluoro hydrocortisone $(20-40 \mathrm{~mm}$. $\mathrm{Hg})$.

Hypercorticoidism.--Rounding of face, acne, and hirsutism varied in relation to the dosage, length of treatment, and patient's physique.

Psychiatric Effects.-Clinical features characteristic of mania was observed in one case treated with metacortandracin and one case treated with 9- $\alpha$-fluoro hydrocortisone.
Progress after Suspension of Treatment.-Relapses occurred on discontinuing treatment in the cases observed up to the present.

The symptoms returned within a few days, causing a rebound relapse, already described by Hench in. cortisone administration.

We never observed patterns of true deterioration of the type defined as "withdrawal syndrome", but the periods of administration are still too short for a final opinion to be expressed.

\section{Metabolic Effects}

Salt and Water Balance.-There was a marked ${ }^{+}$ difference between the effect of 9 - $\alpha$-fluoro hydro- 
METACORTANDRACIN AND 9-ALPHA-FLUORO HYDROCORTISONE ACETATE 255

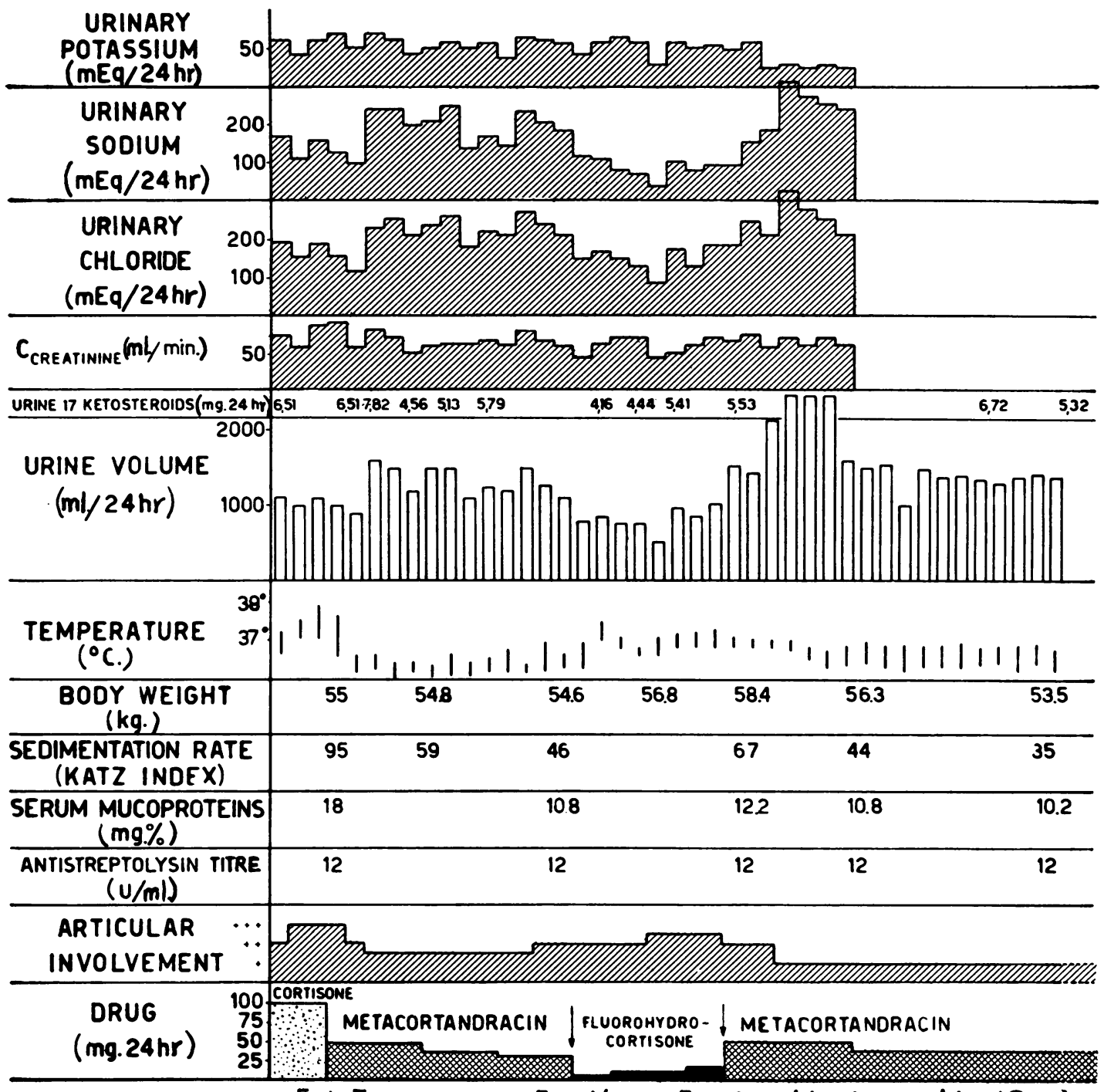

\section{Feb. 3}

Feb.16

Feb.23 Mar.I

Mar.1O Apr. 14

Fig. 2.-Influence of metacortandracin and 9- $\alpha$-fluoro hydrocortisone on clinical symptoms and balance data (Case 5).

cortisone and metacortandracin. The former caused oliguria with retention of $\mathrm{Na}$ and $\mathrm{Cl}$, rapid increase in body weight, and sometimes loss of $\mathrm{K}$ (Figs 1 and 2). The constancy of the endogenous creatinine clearance makes the sodium and chloride retention referable to tubular reabsorption.

Metacortandracin does not produce a positive sodium balance; it is evident from our cases that it has a diuretic effect and increases the elimination of sodium and chloride; the increased output of sodium into the urine may be explained by inhibition of tubular reabsorption (Figs 1 and 2).

Metacortandracin does not markedly modify the concentration of plasma electrolytes, 9- $\alpha$-fluoro hydrocortisone increases plasma sodium and chloride and markedly reduces plasma potassium, to the point of reaching pathological values (Fig. 3, overleaf), with possible alterations of the electrocardiogram by lengthening of Q-T space and displacing the $S-T$ segment, depression of $T$ wave, appearance of $U$ wave. In every case, a fall of haematocrit occurred, as an expression of hydraemia and haemodilution.

Both extracellular and intracellular water increased under 9- $\alpha$-fluoro hydrocortisone, while metacortandracin did not modify the fluids compartments. 


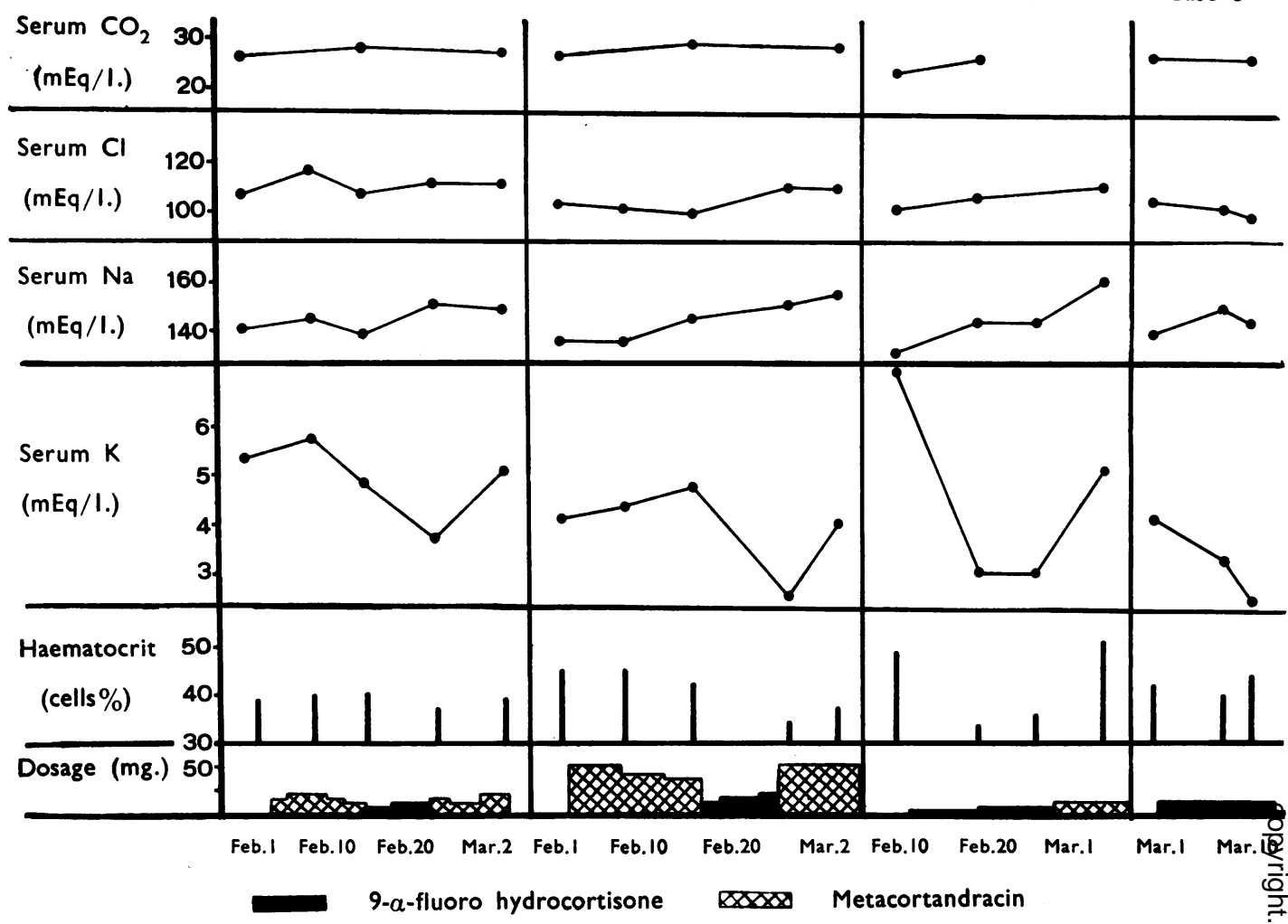

Fig. 3.-Influence of metacortandracin and 9- $\alpha$-fluoro hydrocortisone on serum electrolytes in four typical cases.

Carbohydrate Metabolism.-In four subjects with normal carbohydrate metabolism we determined the effect of both hormones on the glucose tolerance (glucose total load of $0.75 \mathrm{~g} . / \mathrm{kg}$.) and on the sensitivity to insulin (Himmsworth's test: per cent. variations in blood glucose after injection of $30 \mathrm{~g} . / \mathrm{m}^{2}$ glucose and intravenous injection of $5 \mathrm{U} / \mathrm{m}^{2}$ insulin). Both hormones reduced the sensitivity to insulin, and in three cases metacortandracin reduced the glucose tolerance.

We have observed the appearance of glycosuria in one of these cases, and also in another case of acute leukaemia treated with $75 \mathrm{mg}$. metacortandracin daily. In one case with diabetes, metacortandracin caused definite increase of urinary and blood sugar.

Serum Proteins and Cholesterol.-Metacortandracin tended to normalize the serum protein errors present in rheumatoid arthritis, causing increased albumin and reduction in globulins. 9- $\alpha$-fluoro hydrocortisone was less effective probably owing to the shorter duration of treatment.

On serum cholesterol, 9- $\alpha$-fluoro hydrocortisone appears to have no action, but metacortandracin sometimes increased the total serum cholestero

Uric Acid.-The effects on uric acid metabolisnm was studied in two normal and four gouty subjects $\overrightarrow{\overrightarrow{0}}$ In normal subjects 9 - $\alpha$-fluoro hydrocortisone and metacortandracin caused no change in blood urie acid levels; the urinary uric acid seems to fluctuate. more with urine volume than with the administra tion of hormones.

Four cases of gout were treated with metacort $\frac{0}{3}$ andracin: there was a favourable effect on the symptomatology, a slight reduction in blood urie acid, and a slight increase in the daily urinary output of urates. The increased excretion of urates may be attributed to the inhibition of tubularp reabsorption of urates.

Adrenal Function.--Metacortandracin significantly $\mathscr{N}^{\circ}$ and constantly lowered the level of blood eosino 0 phils, while 9- $\alpha$-fluoro hydrocortisone had no such action (Figs 1 and 2).

The levels of urinary 17-ketosteroids were decreased by hormonal administration even in those cases whose excretion was abnormally low, owings to former cortisone therapy. 


\section{Comment}

Metacortandracin was found to have three to five times more anti-rheumatic activity and 9- $\alpha$-fluoro hydrocortisone eight to ten times more than cortisone.

9- $\alpha$-fluoro hydrocortisone exerts a strong mineralocorticoid activity which leads to water and sodium retention and potassium excretion, and to an increase of body fluids in both extracellular and intracellular space; the decrease in plasma potassium was especially marked. These effects explain the increase in body weight and blood volume, the appearance of oliguria and oedema, the increase in blood pressure, bradycardia, and some E.C.G. changes.

On the other hand, metacortandracin does not interfere unfavourably with water and salt balance, and may even increase sodium and water excretion. This absence of water and sodium retention is sufficient for us to consider metacortandracin useful in anti-rheumatic therapy, not only in avoiding secondary phenomena but also in enabling antirheumatic therapy to be extended to cases which were previously considered hazardous, particularly those with active carditis complicated by heart failure.

Both steroids produce a state of hypercorticoidism (acne, hirsutism, rounding of face, etc.) and inhibit adrenal function, as evidenced by the decrease of urinary 17-ketosteroids. The extent of this action will be tested by long-term schedules of treatment.

Biological Considerations.-In metacortandracin the potentiation of the anti-rheumatic and antiphlogistic properties is combined with the loss of one of the most important metabolic actions of corticoid hormones. The possibility of a dissociation between metabolic and anti-phlogistic properties is suggested, and this observation should lead to a further search for steroids with exclusive or predominant anti-inflammatory activity.

The fact that $9-\alpha$-fluoro hydrocortisone is a stronger mineralocorticoid than desoxycorticosterone and also possesses anti-inflammatory properties seems to minimize the possibility of the existence of two groups of opposite corticoids, the former having mineralo-active and prophlogistic properties and the latter glyco-active and antiphlogistic properties.

\section{Summary}

(1) The anti-rheumatic activity of metacortandracin and 9- $\alpha$-fluoro hydrocortisone is 3 to 5 and 8 to 10 times stronger than cortisone.

(2) Metacortandracin does not interfere with salt and water balance; glucose tolerance and insulin sensitivity are decreased; pre-existing diabetes is aggravated.

(3) The absence of mineral activity in metacortandracin represents a step forward in antireactional therapy and allows the extension of anti-rheumatic therapy to forms of active carditis complicated by heart failure.

(4) 9- $\alpha$-fluoro hydrocortisone has a marked mineralocorticoid activity; it increases sodium re-absorption and potassium excretion, and increases both extracellular and intracellular fluids. The serum potassium levels are much reduced, $\mathrm{Na}$ values very slightly increased, and haematocrit values reduced.

(5) The increased effect of $9-\alpha$-fluoro hydrocortisone on electrolytes lessens its usefulness in the treatment of rheumatic diseases.

(6) Both steroids produce a state of hypercorticoidism and inhibit adrenal function; metacortandracin decreases the circulating eosinophils.

(7) Since the anti-rheumatic activity of 9- $\alpha$-fluoro hydrocortisone was demonstrated, no relationship between the mineral and prophlogistic activity of the corticoids has been apparent.

The metacortandracin was kindly supplied by Lepetit S.A., and the 9- $\alpha$-fluoro hydrocortisone by Farmitalia S.A.

\section{REFERENCES}

Ballabio, C. B., Amira, A., Cirla, E., and Sala, G. (1955a). Reumatismo, 7, 113.

10, 74 .,-1955 b). Atti Soc. lombarda Sci. med. biol., , E. W., and Headley, N. E. (1954). Annals of the Rheumatic

Diseases, 13, 291.
Bunim, J. J., Pechet, M. M., and Bollet, A. J. (1955). J. Amer. med. Bunim, J. J., Pechet, 157 .

Sala, G., D', Amico, G., Pasargiklian, E., Amira, A., and Ballabio, C. B. (1955a). Reumatismo, 7, 127.

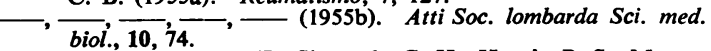

Ward, L. E., Polley, H. F., Slocumb, C. H., Hench, P. S., Mason, H. L., Mattox, V. R., and Power, M. H. (1954). Proc. Mayo Clin., 29, 649.

AdDitional Bibliography

Benedict, S. R., and Franke, E. (1922). J. biol. Chem., 52, 387.

Bloor, W. R. (1916). Ibid., 24, 227.

Bonsnes, R. W., and Taussky, H. H. (1945). Ibid., 158, 581.

Brown, H. (1945). Ibid., 158, 601.

Cachera, R., and Lamotte, M. (1950). Sem. Hôp., Paris, 26, 500.

Callow, N. H., Callow, R. K., and Emmens, C. W. (1938). Biochem. J., 32, 1312.

Dunger, R. (1910). Münch. med. Wschr., 57, 1942.

Forsham, P. H., Thorn, G. W., Prunty, F. T. G., and Hills, A. G. (1948). J. clin. Endocrinol., 8, 15.

Hagedorn, H. C., and Jensen, B. N. (1923). Biochem. Z., 135, 46.

Harvey, S. C. (1910). Arch. intern. Med., 6, 12.

Mosher R. E. Boyle, A. J., Bird, E. J., Jacobson, S. D., Batchelor, T. M., Iseri, L. T., and Myers, G. B. (1949). Amer. J. clin. Path., 19, 461.

Phillips, R. A., and Van Slyke, D. D. Bumed News Lett., Wash., June, 1943

Rantz, L. A., and Randall, E. (1945). Proc. Soc. exp. Biol., 59, 22. Soberman, R., Brodie, B. B., Levy, B. B., Axelrod, J., Hollander, V., and Steele, J. M. (1949). J. biol. Chem., 179, 31.

Sprechler, M. (1950). Acta endocrinol. (Kbh.), 4, 205.

Van Slyke, D. D., and Cullen, G. E. (1917). J. biol. Chem., 30, 289. Van Slyke, D. D., and Cullen, G. E. (1917).

Winzler, R. J., Devor, A. W., Mehi, J. W., and Smyth, I. M. (1948). J. clin. Invest., $27,609$. 
La métacortandracine et l'acétate de 9- $a$-fluoro hydrocortisone dans les malades rhumatismales

\section{RÉSUMÉ}

(1) L'action antirhumatismale de la métacortandracine et de la 9- $\alpha$-fluoro hydrocortisone est 3 à 5 et 8 à 10 fois plus forte que celle de la cortisone.

(2) La métacortandracine ne dérange pas l'équilibre salin et aqueux; diminue la tolérance du glucose et la sensibilité à l'insuline; aggrave le diabète préexistant.

(3) Le fait que la métacortandracine n'agit pas sur les minéraux est un grand pas dans la thérapie antiréactionnelle et permet d'appliquer le traitement antirhumatismal aux formes de cardite active compliquée d'insuffisance cardiaque.

(4) La 9-a-fluoro hydrocortisone a une action minéralocorticoide marquée: elle augmente la reabsorption du sodium, l'excrétion du potassium et la rétention liquide intra et extracellulaire. Le taux sérique du potassium est très réduit, celui du sodium un peu augmenté et le chiffre obtenu au moyen de l'hématocrite est diminué.

(5) La plus forte action de la 9-a-fluoro hydrocortisone sur les électrolytes la rend moins utile dans le traitement des maladies rhumatismales.

(6) Les deux stéroïdes produisent un état d'hypercorticoidisme et inhibent la fonction surrénale; la métacortandrine diminue le chiffre sanguin des éosinophiles.

(7) A la suite de la découverte de l'action antirhumatismale de la 9-a-fluoro hydrocortisone, on n'a observé aucun rapport entre l'action des corticoïdes sur les minéraux et sur l'inflammation.
La metacortandracina y el acetato de 9- $\alpha$-fluoro hidrocortisona en las enfermedades reumáticas

SUMARIO

(1) La acción antirreumática de la metacortandracina y de la 9- $a$-fluoro hidrocortisona es 3 a 5 y 8 a 10 veces $\Rightarrow$ más fuerte que la de la cortisona.

(2) La metacortandracina no estorba el equilibrio salino o acuoso; disminuye la tolerancia de la glucosa y $\frac{\bar{c}}{\mathrm{a}}$ la sensibilidad a la insulina; agrava la diabetes existente.

(3) El hecho de que la metacortandracina no tiene acción mineral constituye un adelanto de la terapia $\stackrel{\varnothing}{\varrho}$ antirreaccional, ya que facilita el tratamiento antirreumático de las formas de carditis activa con insuficiencia cardiaca.

(4) La 9- $a$-fluoro hidrocortisona tiene una acción $:$ mineralocorticoide marcada: aumenta la reabsorpción $\vec{\omega}$ de sodio, la excreción de potasio y la retención líquida intra y extracelular. Las cifras séricas de potasio se ven reducidas, las de sodio algo aumentadas y los valores de $\bar{\alpha}$ hematocrito disminuidos.

(5) Por su acción más fuerte sobre electrolitos, la 9- $a$-fluoro hidrocortisona es menos util en el tratamiento $\omega$ de las enfermedades reumáticas.

(6) Ambos esteroides producen un estado de hiper- corticoidismo e inhiben la función suprarrenal; la meta- 음 cortandracina hace bajar las cifras sanguíneas de eosinófilos.

(7) La descubierta de la acción antirreumática de $\mathbb{D}$ la 9-a-fluoro hidrocortisona no reveló relación $\frac{+}{\mathbb{D}}$ alguna entre la acción mineral y antiflogística de los corticoides.

\section{ADDENDUM}

Since this paper was first submitted to the editor, we have treated 67 more cases of rheumatic disease with metacortandracin (Prednisone) or metacortandralone (Prednisolone). The results confirm those described above. We wish, however, to emphasize the possibility of deterioration on with- drawal. This was observed in three patients with rheumatoid arthritis after suspension of treatment. In these three patients the urinary excretion of 17-ketosteroids was lowered, so that the relapses 0 may have been due to the inhibition of adrenal $\overrightarrow{0}$ function. 